\title{
Induced Release of a Plant-Defense Volatile 'Deceptively' Attracts Insect Vectors to Plants Infected with a Bacterial Pathogen
}

\author{
Rajinder S. Mann ${ }^{1}$, Jared G. Ali ${ }^{1}$, Sara L. Hermann ${ }^{1}$, Siddharth Tiwari ${ }^{1}$, Kirsten S. Pelz-Stelinski ${ }^{1}$, \\ Hans T. Alborn ${ }^{2}$, Lukasz L. Stelinski ${ }^{1 *}$
}

1 University of Florida, Entomology and Nematology Department, Citrus Research and Education Center, Lake Alfred, Florida, United States of America, 2 Center for Medical, Agricultural, and Veterinary Entomology, Agricultural Research Service, U.S. Department of Agriculture, Gainesville, Florida, United States of America

\begin{abstract}
Transmission of plant pathogens by insect vectors is a complex biological process involving interactions between the plant, insect, and pathogen. Pathogen-induced plant responses can include changes in volatile and nonvolatile secondary metabolites as well as major plant nutrients. Experiments were conducted to understand how a plant pathogenic bacterium, Candidatus Liberibacter asiaticus (Las), affects host preference behavior of its psyllid (Diaphorina citri Kuwayama) vector. $D$. citri were attracted to volatiles from pathogen-infected plants more than to those from non-infected counterparts. Las-infected plants were more attractive to $D$. citri adults than non-infected plants initially; however after feeding, psyllids subsequently dispersed to non-infected rather than infected plants as their preferred settling point. Experiments with Lasinfected and non-infected plants under complete darkness yielded similar results to those recorded under light. The behavior of psyllids in response to infected versus non-infected plants was not influenced by whether or not they were carriers of the pathogen. Quantification of volatile release from non-infected and infected plants supported the hypothesis that odorants mediate psyllid preference. Significantly more methyl salicylate, yet less methyl anthranilate and D-limonene, was released by infected than non-infected plants. Methyl salicylate was attractive to psyllids, while methyl anthranilate did not affect their behavior. Feeding on citrus by $D$. citri adults also induced release of methyl salicylate, suggesting that it may be a cue revealing location of conspecifics on host plants. Infected plants were characterized by lower levels of nitrogen, phosphorus, sulfur, zinc, and iron, as well as, higher levels of potassium and boron than non-infected plants. Collectively, our results suggest that host selection behavior of $D$. citri may be modified by bacterial infection of plants, which alters release of specific headspace volatiles and plant nutritional contents. Furthermore, we show in a laboratory setting that this apparent pathogen-mediated manipulation of vector behavior may facilitate pathogen spread.
\end{abstract}

Citation: Mann RS, Ali JG, Hermann SL, Tiwari S, Pelz-Stelinski KS, et al. (2012) Induced Release of a Plant-Defense Volatile 'Deceptively' Attracts Insect Vectors to Plants Infected with a Bacterial Pathogen. PLoS Pathog 8(3): e1002610. doi:10.1371/journal.ppat.1002610

Editor: Sanford Eigenbrode, University of Idaho, United States of America

Received September 27, 2011; Accepted February 13, 2012; Published March 22, 2012

This is an open-access article, free of all copyright, and may be freely reproduced, distributed, transmitted, modified, built upon, or otherwise used by anyone for any lawful purpose. The work is made available under the Creative Commons CCO public domain dedication.

Funding: Funding for this research was provided by the Citrus Research and Development Foundation Inc. Florida. The funders had no role in study design, data collection and analysis, decision to publish, or preparation of the manuscript.

Competing Interests: The authors have declared that no competing interests exist.

*E-mail: stelinski@ufl.edu

\section{Introduction}

Transmission of plant pathogens by insect vectors is a complex biological process involving interactions between the plant, insect, and pathogen [1-2]. Pathogens can induce changes in the traits of their primary hosts as well as their vectors to affect the frequency and nature of interactions between hosts and vectors [3-13]. Plant morphology, as well as, primary and secondary plant compounds, including emitted volatiles and plant nutrients, are some of the traits that can be altered by pathogen infection of plants [14-16]. Fecundity, survival, and behavior are primary traits altered in insect vectors due to such infection [7-10,12-13,17-21]. Plant pathogen infection may alter both plant morphology and chemistry; therefore, research efforts have focused on the vector's response to such changes in their plant host [7-12,18-21].

Candidatus Liberibacter asiaticus (Las) is a gram-negative, fastidious, phloem-limited bacterium that causes huanglongbing (HLB) disease in citrus [20]. Based on their 16S rRNA gene sequence, three species of the pathogen have been identified to date: 1) Candidatus Liberibacter asiaticus (Las), 2) Candidatus Liberibacter africanus (Laf), and 3) Candidatus Liberibacter americanus (Lam) [22-26]. Each species can be graft-inoculated into plants with infected plant tissue [22-23,27-29]. Las and Lam are transmitted by the Asian citrus psyllid, Diaphorina citri Kuwayama (Hemiptera: Psyllidae); whereas, Laf is transmitted by the African citrus psyllid, Trioza erytreae (Del Guercio) (Hemiptera: Psyllidae). Both D. citri adults and nymphs are capable of transmitting Las after feeding on an infected plant for 30 minutes or longer [19,30-32]. If the pathogen is acquired by psyllid nymphs, adults are capable of transmitting the bacteria immediately after emergence $[19,30,33]$. The bacteria presumably multiply within the vector and are retained throughout the entire life cycle of the vector [33-34].

HLB, otherwise known as citrus greening disease, is one of the most devastating diseases of citrus worldwide [22,28,35]. HLB affects plant phloem, causing yellow shoots, mottling, chlorosis, and twig die back that result in rapid tree decline and ultimately tree death. In areas of the world where HLB is endemic, citrus 


\section{Author Summary}

In this investigation, we experimentally demonstrate specific mechanisms through which a bacterial plant pathogen induces plant responses that modify behavior of its insect vector. Candidatus Liberibacter asiaticus, a fastidious, phloem-limited bacterium responsible for causing huanglongbing disease of citrus, induced release of a specific volatile chemical, methyl salicylate, which increased attractiveness of infected plants to its insect vector, Diaphorina citri, and caused vectors to initially prefer infected plants. However, the insect vectors subsequently dispersed to non-infected plants as their preferred location of prolonged settling because of likely sub-optimal nutritional content of infected plants. The duration of initial feeding on infected plants was sufficiently long for the vectors to acquire the pathogen before they dispersed to non-infected plants, suggesting that the bacterial pathogen manipulates behavior of its insect vector to promote its own proliferation. The behavior of psyllids in response to infected versus noninfected plants was not influenced by whether or not they were carriers of the pathogen and was similar under both light and dark conditions. Feeding on citrus by $D$. citri adults also induced the release of methyl salicylate, suggesting that it may be a cue revealing location of conspecifics on host plants.

trees decline and die within a few years and may never produce usable fruit [28]. All commercial citrus cultivars are susceptible to HLB and there is no cure currently. HLB spread is dependent upon the density and movement of $D$. citri from infected trees to uninfected trees [36]. Mating and oviposition in D. citri occurs exclusively on the new and tender flush of its host plants [37-38]. In addition, $D$. citri is known to use combined olfactory and visual cues to locate citrus host plants [39-40].

Many plant species emit volatiles in response to arthropod feeding or pathogen attack [41-43]. Plants can defend themselves by producing infochemicals or toxins that act directly against herbivores or indirectly by producing chemicals, which attract herbivore natural enemies [44-49]. Several metabolic pathways are activated in plants when pathogens invade [49-50]. Some metabolites accumulate in leaves, whereas others are only produced in a particular type of induction [50-53]. For example, biosynthesis of the phenolic defense hormone, salicylic acid (SA), and its conversion to derivatives such as salicylic acid $\beta$-glucoside, salicylic acid glucose ester, and methyl salicylate (MeSA), are major and general metabolic events in pathogen-infected plants [50,54-55]. Such plant hormone-mediated responses affect the interactions between pathogens and herbivores on plants in many ways [56].

Pathogens can also induce the release of chemicals from plants that benefit their survival and spread or suppress plants' defense responses [16,57]. For example, infection of apple with Candidatus Phytoplasma mali, (causal agent of apple proliferation) induces release of $\beta$-caryophyllene, which attracts apple psyllids (Cacopsylla picta) to infected trees and facilitates pathogen spread [16]. Similarly, cucumber mosaic virus (CMV)-, potato leaf roll virus (PLRV)- and barley yellow dwarf virus (BYDV)-infected plants are more attractive to their aphid vectors, Aphis gossypii, Myzus persicae and Rhopalosiphum padi or Schizaphis graminum, than non-infected plants due to induced production of volatiles as a result of infection [3-4,58-59]. CMV was reported to reduce the quality of squash plants for M. persicae and A. gossypii [9]. Similarly, BYDV reduced the quality of wheat plants for $R$. padi [12]. In contrast, PLRV improved the quality of potato plants as hosts to its vector, $M$. persicae [13].

Although most investigations of plant-pathogen interactions have focused on individual aspects of pathogen-induced plant defense [50,54-55] or the response of insect vectors to infected versus non-infected plants [9,15-16], studies are emerging which highlight multiple interactions between herbivores and phytopathogens $[9,47,56,60]$. The goal of current research was to understand the interactions between the pathogen (Las), the vector $(D$. citr $)$, and the host plant (citrus) to determine whether pathogen-induced plant response may facilitate spread of the HLB pathogen. The specific objectives were to determine whether pathogen infection alters the attractiveness of host plants to the vector and to determine how infection of the vector with the pathogen affects its behavioral response. To assess the effects of Las infection on vector-plant interactions, we conducted olfactometer and gas chromatography-mass spectroscopy (GC-MS) assays to identify specific olfactory cues attractive to psyllid vectors. In addition, we evaluated the effect of olfactory cues on the settling and dispersal behaviors of psyllids. Our results indicate apparent pathogen-mediated manipulation of vector behavior, which may promote pathogen spread.

\section{Results}

\section{Response of psyllids to host plant odors}

The majority $(>80 \%)$ of those $D$. citri tested responded to the odors of either non-infected or Las-infected citrus plants. Significantly more $D$. citri males $\left(\chi^{2}=4.32\right.$, $\left.\mathrm{df}=1, \mathrm{P}=0.04\right)$ and females $\left(\chi^{2}=6.53, \mathrm{df}=1, \mathrm{P}=0.01\right)$ were attracted to the odors from Las-infected plants than non-infected plants (Fig. 1). Lasinfected male $\left(\chi^{2}=5.24, \mathrm{df}=1, \mathrm{P}=0.02\right)$ and female $\left(\chi^{2}=4.37\right.$, $\mathrm{df}=1, \mathrm{P}=0.04)$ psyllids were also more attracted to the odors from infected than non-infected plants (Fig. 1). No significant differences were detected when $D$. citri adults were exposed to non-infected grafted (sham grafted) vs. non-grafted-non-infected plants $\left(\chi^{2}=1.51, \mathrm{df}=1, \mathrm{P}=0.22\right)$.

\section{Host plant selection under light or dark conditions}

Light conditions. Observation time and Las infection status of $D$. citri, and gender of $D$. citri did not significantly affect the number of $D$. citri that settled on Las-infected versus non-infected plants $(\mathrm{F}=2.63, \mathrm{df}=1,30, \mathrm{P}=0.12$ and $\mathrm{F}=0.09, \mathrm{df}=1,24$, $\mathrm{P}=0.76$, respectively). However, significantly more female $D$. citri landed on Las-infected than on non-infected plants $(\mathrm{F}=5.70$, $\mathrm{df}=1,24, \mathrm{P}=0.03)$. Las infection status of plants significantly interacted with observation time $(\mathrm{F}=160.07, \mathrm{df}=1,30, \mathrm{P}<0.001)$.

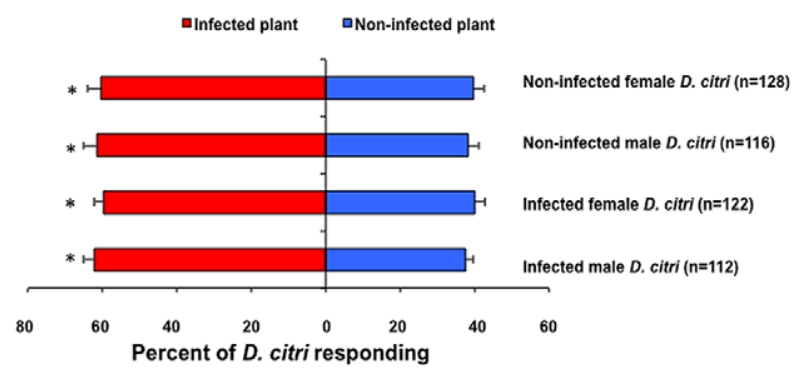

Figure 1. Response of $D$. citri to odors emitted from Lasinfected versus non-infected citrus in a laboratory olfactometer. Bars labeled by an asterisk are significantly different $\left(\chi^{2}\right.$ test, $\mathrm{p}<0.05) . \mathrm{n}=$ total number of psyllids that responded. doi:10.1371/journal.ppat.1002610.g001 
More adult $D$. citri (of either gender and infection status) landed upon Las-infected plants than on non-infected plants three d after release (Fig. 2A). However, more adult D. citri were found on noninfected plants than on Las-infected plants seven d after release (Fig. 2A). Non-infected plants remained Las-negative when examined four months after exposure to Las-infected or noninfected $D$. citri in behavioral assays.

Dark conditions. Observation time, Las infection status of $D$. citri, and gender of $D$. citri did not significantly affect the number of $D$. citri that settled on Las-infected versus non-infected plants $(\mathrm{F}=1.67, \mathrm{df}=1,30, \mathrm{P}=0.21 ; \mathrm{F}=3.36, \mathrm{df}=1,24, \mathrm{P}=0.08 ;$ and $\mathrm{F}=1.70, \mathrm{df}=1,24, \mathrm{P}=0.21$, respectively). Las infection status of plants significantly interacted with observation time $(\mathrm{F}=49.45$, $\mathrm{df}=1,30, \mathrm{P}<0.001$ ). More adult $D$. citri (of either gender or infection status) landed on Las-infected plants than on noninfected plants three d after release (Fig. 2B). However, more adult D. citri were found on non-infected plants than on Las-infected plants seven d after release (Fig. 2B). Non-infected plants remained Las-negative when examined four months after exposure to Lasinfected or non-infected D. citri in behavioral assays.

\section{Movement of $D$. citri between Las-infected and uninfected plants}

Movement of non-infected or Las-infected D. citri from Lasinfected to non-infected plants was greater than observed for any other treatment combination $(\mathrm{F}=24.95, \mathrm{df}=3,24, \mathrm{P}<0.0001)$ (Fig. 3). More Las-infected D. citri tended to move than uninfected counterparts after initial settling, although this difference was not statistically significant $(F=3.70, d f=1,24, P=0.07)$. Las infection status of psyllids did not interact significantly with the direction of movement between plant treatments $(\mathrm{F}=0.91, \mathrm{df}=3,24$,

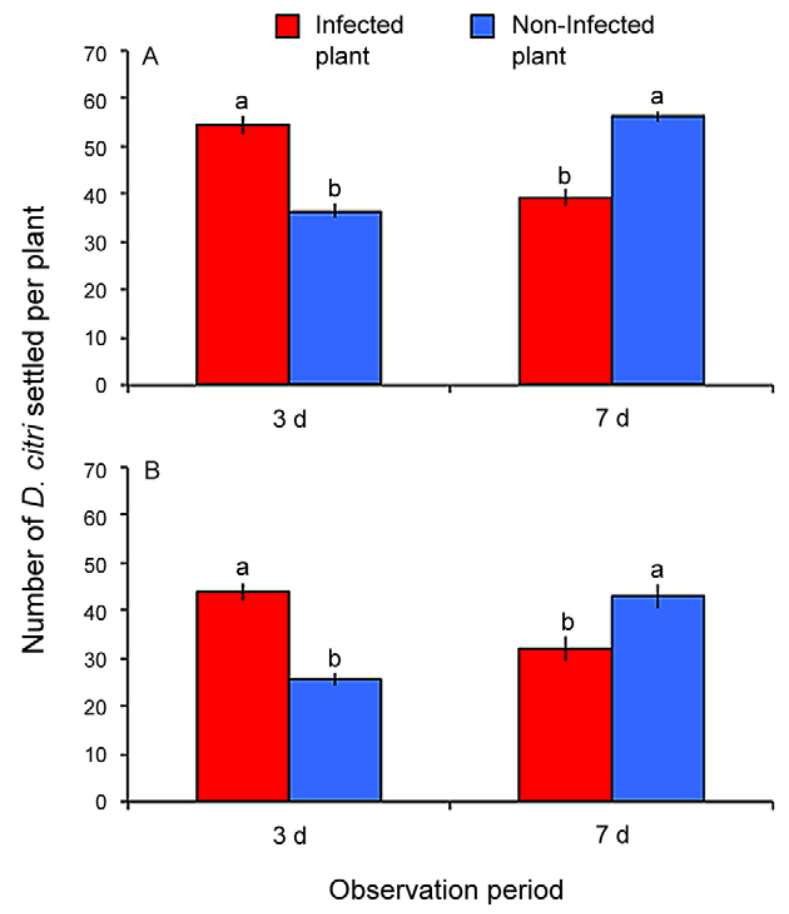

Figure 2. Settling preference of combined non-infected and Las-infected $D$. citri on Las-infected versus non-infected citrus plants. Panel (A) shows response under light conditions and panel (B) shows response under dark conditions. Bars with the same letter are not significantly different (Tukey's HSD test, $\mathrm{p}<0.05$ ).

doi:10.1371/journal.ppat.1002610.g002
$\mathrm{P}=0.45$ ). Approximately $5 \%$ of non-infected psyllids moving from infected to non-infected plants acquired the Las bacterium (Table 1). Four months after the termination of the experiment, all of the non-infected plants that had been inserted into cages with Las-positive plants tested positive for Las (Table 1).

\section{Nutritional status of Las-infected and non-infected citrus plants}

There were marked differences between infected and non-infected plants with respect to nutrient content (Table 2). Las-infected plants were deficient in nitrogen, phosphorus, magnesium, zinc, and iron as compared with non-infected plants (Table 2). However, Las-infected plants had higher potassium and boron contents compared with non-infected plants (Table 2). There were no differences between Las-infected and non-infected plants for calcium, sulfur, silicon, manganese, sodium, molybdenum, aluminum, and chlorine.

\section{Feeding efficiency of $D$. citri on non-infected versus infected plants}

The number of honey dew droplets produced by psyllid feeding, a surrogate measure of feeding efficiency, was significantly affected by the infection status of plants $(\mathrm{F}=65.99$, $\mathrm{df}=1,39, \mathrm{P}<0.0001)$, feeding exposure time $(\mathrm{F}=81.81, \mathrm{df}=3,24, \mathrm{P}<0.0001)$, and the interaction between the two factors $(\mathrm{F}=7.11, \mathrm{df}=3,28, \mathrm{P}=0.0011)$. There was no significant difference in the amount of feeding on noninfected versus infected plants after $24 \mathrm{~h}$ of feeding by psyllids (Fig. 4). However, psyllids fed significantly more on non-infected than on Las-infected plants after 48, 72 and 96 h, respectively.

\section{Volatile release by Las-infected and non-infected citrus plants}

There were significant qualitative and quantitative (Table 3, Fig. 5) differences between the headspace volatiles of non-infected and Las-infected plants (Table 3). Las-infected plants released significantly more MeSA than non-infected plants (Table 3, Fig. 5), while non-infected plants released more methyl anthranilate (MeAN) and D-limonene than infected plants (Table 3). Using a Random Forests algorithm, a minimum of two compounds, MeAN and MeSA, were identified that discriminated between the infected and non-infected volatile organic compound (VOC) signatures of these treatments, with an estimate prediction error of 0.15 and a 'leave-one-out' bootstrap error of 0.20 .

\section{Volatile release before and during psyllid feeding}

A significant amount of MeSA was detected in headspace volatiles from plants after psyllids were introduced and allowed to feed, as compared with headspace volatiles from plants prior to psyllid feeding $(t=-2.97, \mathrm{df}=5, \mathrm{P}=0.03)$. MeSA was detected in headspace profiles from plants infested with female as well as male psyllids; however, there was no significant difference in the amount of MeSA released in response to male verses female feeding $(\mathrm{t}=0.27, \mathrm{df}=4, \mathrm{P}=0.80)$. Analysis of the volatile profiles of plants prior to the introduction of psyllids of either sex or from negative control plants yielded no MeSA. The amount of MeSA released (mean $\pm \mathrm{SE}$ ) by plants exposed to psyllid feeding (10.3 $\pm 3.00 \mathrm{ng} /$ plant $/ 24 \mathrm{hr}$ ) was similar to the amount released by Las-infected plants $(12.87 \pm 4.78 \mathrm{ng} /$ plant/24 hr), and both of these amounts were similar to the quantity of synthetic MeSA found to be attractive to psyllids in behavioral bioassays (Table 4).

\section{Behavioral response of $D$. citri to synthetic chemicals}

Behavioral bioassays with synthetic chemicals identified from Las-infected and non-infected plants revealed that D. citri were 


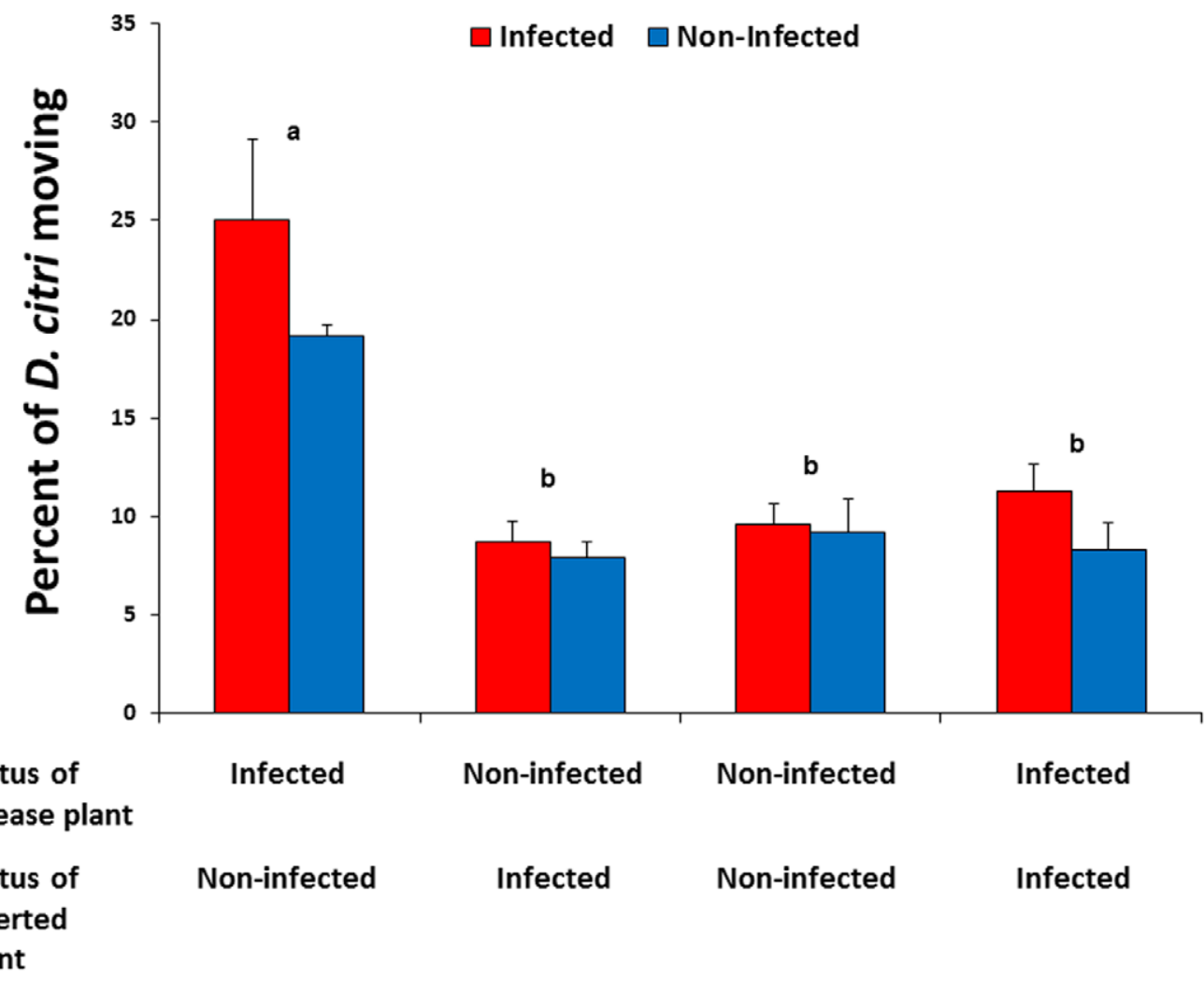

Figure 3. Movement of previously settled $D$. citri from Las-infected to non-infected citrus plants. Red bars show the response of Lasinfected psyllids and blue bars show the response of non-infected psyllids; no significant differences were detected between psyllid types within plant treatments. Pairs of bars representing plant treatment combinations labeled with different letters are significantly different from one another (Tukey's HSD test, $\mathrm{p}<0.05$ ).

doi:10.1371/journal.ppat.1002610.g003

significantly attracted to MeSA at the $0.01 \mu \mathrm{g}$ dosage, but that they were repelled by this chemical at the $100 \mu \mathrm{g}$ dosage (Table 4). D. citri were attracted to D-limonene only at the $100 \mu \mathrm{g}$ dosage, while MeAN did not attract or repel $D$. citri at any of the dosages tested. The positive control ( $\beta$-ocimene) was attractive at $1-100 \mu \mathrm{g}$ dosages (Table 4).

\section{Discussion}

Our results indicate that Las-infected plants were initially more attractive to $D$. citri adults than non-infected plants; however, psyllids dispersed subsequently to non-infected plants after initially settling on infected plants. Similar results obtained with the behavioral responses of $D$. citri under both light and dark conditions suggest that initial movement of psyllids to Las-infected plants is likely mediated by volatile cues. Infection of citrus with this plant pathogen induced release of MeSA, which attracted $D$. citri. A similar amount of MeSA was also released by similar trees in response to $D$. citri infestation, suggesting that the same cue exploited by the pathogen to attract its vector may be used by the vector to locate congregations of conspecifics feeding on noninfected plants. Following initial chemically mediated attraction to

Table 1. Las infection status of inserted plants and Diaphorina citri migrating from initial point of forced settling to subsequently inserted plant treatments.

\begin{tabular}{llll}
\hline & & & \\
\hline Initial plant & Inserted plant & $\begin{array}{l}\text { Las infection status } \\
\text { of released } D \text {. citri }\end{array}$ & $\begin{array}{l}\text { \% of inserted plants } \\
\text { infected with Las }\end{array}$ \\
\hline Non-infected & Infected & Non-infected & 100 \\
Non-infected & Infected & Infected & 100 \\
Non-infected & Non-infected & Non-infected & 0.0 \\
Non-infected & Non-infected & Infected & 71.2 \\
Infected & Infected & Non-infected & 100 \\
Infected & Infected & Infected & 100 \\
Infected & Non-infected & Non-infected & 100 \\
Infected & Non-infected & Infected & 0.0 \\
\hline doi:10.1371/journal.ppat.1002610.t001 & & 100 \\
\hline
\end{tabular}


Table 2. Differing levels of various nutrients between Las-infected and non-infected Citrus sinensis plants.

\begin{tabular}{|c|c|c|c|c|c|c|c|c|c|c|c|c|c|c|}
\hline Plant status & $\mathbf{N}$ & $\mathbf{P}$ & $\mathbf{K}$ & Mg & $\mathrm{Ca}$ & $\mathbf{s}$ & B & $\mathrm{Zn}$ & Mn & $\mathrm{Fe}$ & $\mathbf{S i}$ & $\mathrm{Na}$ & Mo & Al \\
\hline Uninfected plant & 3.13 & 0.17 & 3.00 & 0.43 & 1.88 & 0.25 & 46.67 & 29.33 & 39.00 & 86.33 & 0.15 & 0.08 & 0.02 & 35.34 \\
\hline Las-infected plant & 2.32 & 0.11 & 4.05 & 0.29 & 1.75 & 0.24 & 76.00 & 19.67 & 35.33 & 66.67 & 0.16 & 0.11 & 0.01 & 16.98 \\
\hline $\mathrm{t}$ value & 8.03 & 3.72 & 19.10 & 8.67 & 1.67 & 0.42 & 12.35 & 45.85 & 1.21 & 16.75 & 0.43 & 1.69 & 0.42 & 2.08 \\
\hline$P$ value & $<0.01^{*}$ & 0.01 & $<0.01^{*}$ & $<0.01^{*}$ & 0.15 & 0.69 & $<0.01^{*}$ & $<0.01^{*}$ & 0.28 & $<0.01^{*}$ & 0.68 & 0.14 & 0.69 & 0.09 \\
\hline
\end{tabular}

Nutrient values in columns labeled with * are significantly different at $\mathrm{p}<0.05$ (two-sample $\mathrm{t}$-test). Values for nitrogen (N), phosphorus (P), potassium (K), manganese (Mg), Calcium (Ca), Sulfur (S), silicon (Si), and sodium ( $\mathrm{Na}$ ) are in \% while values for boron (B), zinc (Zn), manganese (Mn), iron (Fe), molybdenum (Mo), and aluminum (Al) are in ppm.

doi:10.1371/journal.ppat.1002610.t002

infected plants, psyllids tended to subsequently disperse to noninfected plants, making them their preferred settling choice. We speculate that this may have been due to the sub-optimal quality of infected plants as compared with non-infected plants, as evidenced by lower feeding efficiency on infected than non-infected leaves. Importantly, this pathogen-manipulated behavioral sequence facilitated pathogen spread by the vector in a controlled laboratory experiment.

Our results suggest that an insect-transmitted bacterial plant pathogen alters plant traits so as to induce odor-mediated behavior from the vector that may ultimately benefit the pathogen. While increased preference of insect vectors to virus-infected versus noninfected host plants has been demonstrated for both persistently and non-persistently transmitted viruses $[3,4,9]$, little is known about similar interactions involving pathogenic bacteria. Furthermore, most previous studies on pathogen-vector interactions have focused on single mechanisms (olfactory, visual or nutritional) [1516,61-64]. In the current investigation, we sought to determine several underlying mechanisms (chemical, visual, and nutritional) that affect the behavior of an insect $(D$. citri) in response to plant infection by the pathogen (Candidatus Liberibacter asiaticus) that it transmits.

Volatiles from infected and non-infected citrus are attractive to D. citri as confirmed by the current data and previous studies [40]. $D$. citri were attracted to common volatiles released by citrus such as $\beta$-ocimene and D-limonene, implicating these as general host selection cues. Both $\beta$-ocimene and D-limonene are predominant citrus volatiles released by citrus flush, foliage, and fruit [40,6567]. However, pathogen infection induced release of certain novel components or a quantitative increase in release of certain



Figure 4. Feeding efficiency of $D$. citri on Las-infected versus non-infected citrus leaves as measured by honeydew excretion. Bars labeled with different letters are significantly different from one another (Tukey's HSD test, $p<0.05$ ).

doi:10.1371/journal.ppat.1002610.g004 compounds that were released in lower quantities by non-infected plants. Among the novel chemicals identified that distinguished Las-infected from non-infected plants, only MeSA elicited attraction from $D$. citri and may explain the enhanced attractiveness of infected plants. However, the effect of MeSA on D. citri behavior, as part of a complex citrus volatile blend, requires further investigation. Specific blends of plant volatiles are important for attraction of herbivores to their host plants; however, individual components of such blends can act as repellents when not perceived within the context of the entire blend [68-69].

Movement of psyllids from infected to non-infected plants after initial selection of infected plants suggests that their initial response to olfactory cues may not be directly linked to the most beneficial host plant. This was also confirmed by feeding assays measured by honeydew excretion. These results suggest that psyllids must feed on infected plants in order to discern poor quality of the host. Therefore, volatiles appear to be involved in host finding, but not in arrestment on the host. Feeding is required for insects to differentiate between non-infected and infected plants and gustatory cues are involved in host acceptance [57,70-71].

Insect herbivory can change the volatile profile of host plants. Insects that use a piercing/sucking mode of feeding have longlasting interactions with plants cells and/or phloem [44]. It may not be surprising that plant responses to phloem-feeding are distinct from those occurring in response to chewing insects and that phloem-feeders often induce salicylate-dependent defense pathways commonly activated by bacterial, fungal, and viral pathogens [44,56,72-73]. A salicylate-dependent association is implicated in the current investigation given detection of MeSA release from plants infected with the Las pathogen. Production of $\mathrm{MeSA}$ is associated with the phytohormone, salicylic acid (SA), and its role in signaling plant defensive pathways, which regulate systemic acquired resistance against a wide variety of invading pathogens [74-75]. Zarate et al. [76] demonstrated that the whitefly, Bemisia tabaci, induces SA-signaling pathways, which suppress basal defenses constraining nymph development. Thus, attraction to plants with high levels of SA-signaling may benefit the herbivore. Furthermore, suppression of defenses via SA may be consistent with a number of strategies employed by phloemfeeding insects to avoid such defenses (see Walling [77]).

We investigated whether release of MeSA may be induced by $D$. citri feeding as a possible cue used by psyllids for locating established conspecifics or plants that have suppressed basal defenses. Volatile collections from psyllid-infested plants detected induced release of MeSA, suggesting a coincidental convergence on a single cue that may simultaneously benefit the pathogen by deceptively attracting its vector, which also uses this cue to locate conspecifics or identify vulnerable hosts. Broadly, these results are 
Table 3. Volatiles from Las-infected and non-infected citrus plants presented as average percentage \pm 1 standard error (SE) of $n$ octane equivalents of volatile organic compounds collected from plants' headspace.

\begin{tabular}{|c|c|c|c|c|c|c|}
\hline Compound & RT & CAS \# ${ }^{*}$ & Uninfected (Mean $\% \pm$ SE) & Las-infected (Mean $\% \pm \mathrm{SE}$ ) & $t$-value (df) & P-value \\
\hline Sabiene & 7.94 & $3387-41-5$ & $11.0 \pm 2.54$ & $15.0 \pm 0.67$ & $-0.55(8)$ & 0.60 \\
\hline$\beta$-pinene & 8.01 & $127-91-3$ & $0.01 \pm 0.001$ & $0.01 \pm 0.001$ & $-0.135(8)$ & 0.90 \\
\hline Myrcene & 8.2 & $123-35-3$ & $3.0 \pm 0.44$ & $3.0 \pm 0.23$ & $0.27(8)$ & 0.79 \\
\hline 3-Carene & 8.57 & $13466-78-9$ & $5.0 \pm 1.09$ & $2.0 \pm 0.08$ & $1.12(8)$ & 0.39 \\
\hline D-limonene & 8.71 & $5989-27-5$ & $59.0 \pm 3.18$ & $27.0 \pm 0.79$ & $3.67(8)$ & $0.01 *$ \\
\hline$\beta$-ocimene & 8.95 & $502-99-8$ & $6.0 \pm 1.01$ & $6.0 \pm 0.5$ & $-0.30(8)$ & 0.77 \\
\hline Linalool & 9.83 & $78-70-6$ & $2.0 \pm 0.56$ & $1.0 \pm 0.11$ & $0.48(8)$ & 0.65 \\
\hline Menthatriene (1,3,8-para) & 10.14 & $18368-95-1$ & $0.01 \pm 0.001$ & $4.0 \pm 0.25$ & $-2.21(8)$ & 0.06 \\
\hline Methyl salicylate & 11.01 & $119-36-8$ & $1.0 \pm 0.21$ & $39.0 \pm 2.86$ & $-3.06(8)$ & $0.02 *$ \\
\hline Geranial & 12.21 & $141-27-5$ & $2.0 \pm 0.45$ & $0.0 \pm 0.0$ & $2.10(8)$ & 0.07 \\
\hline Methyl anthranilate & 13.9 & 134-20-3 & $12.0 \pm 1.25$ & $0.01 \pm 0.05$ & $3.24(8)$ & $0.01 *$ \\
\hline Caryophyllene & 14.45 & $87-44-5$ & $0.01 \pm 0.02$ & $3.0 \pm 0.22$ & $-2.06(8)$ & 0.07 \\
\hline
\end{tabular}

Each compound is characterized by its retention time (RT) and major ion.

Bold values indicate a significant difference between treatments $(P<0.05)$. The chemicals which were present in different proportions between Las-infected and noninfected citrus plants are shown. Identification was based on comparisons of retention times with standard and spectral data from Adams, EPA, Nist05 Libraries and synthetic standard comparison.

${ }^{*}$ CAS \#: Chemical Abstract Service number.

doi:10.1371/journal.ppat.1002610.t003

consistent with the "deceptive host phenotype" hypothesis proposed by Mauck et al. [9], given that release of an existing cue that attracts the vector (MeSA) to its host plant was also induced by pathogen infection, thus deceptively attracting the vector to nutritionally sub-optimal hosts.

Pathogen-induced release of plant volatiles has been previously established following virus infection. In these cases, CMV, PLRV, and BYDV induced release of volatiles that rendered infected plants more attractive to their aphid vectors than non-infected plants. Both PLRV and BYDV infections improved the quality of the host plants to their respective vectors [3,4,78-79], resulting in preferential arrestment on the infected plants due to contact and gustatory cues $[3,4,58]$. Our results are similar to the findings of Mauck et al [9], where squash plants infected with CMV released volatiles that initially attracted the aphid vector, but were poor hosts for their vectors, causing subsequent movement from infected to non-infected plants. Possible pathogen-mediated manipulation of vector behavior may depend on how pathogens are transmitted. Persistent pathogens, which require longer feeding durations for acquisition, benefit from increased arrestment of their vector, while non-persistent or semi-persistent pathogens may induce changes in plant phenotype that cause vectors to quickly disperse following acquisition [9]. In our experiments, psyllids were initially attracted to infected plants, but later preferred to settle on non-infected hosts. Therefore, our results with a bacterial plant pathogen appear to share similarities with previous results obtained with both non-persistent and persistent plant viruses. Although $D$. citri were initially attracted

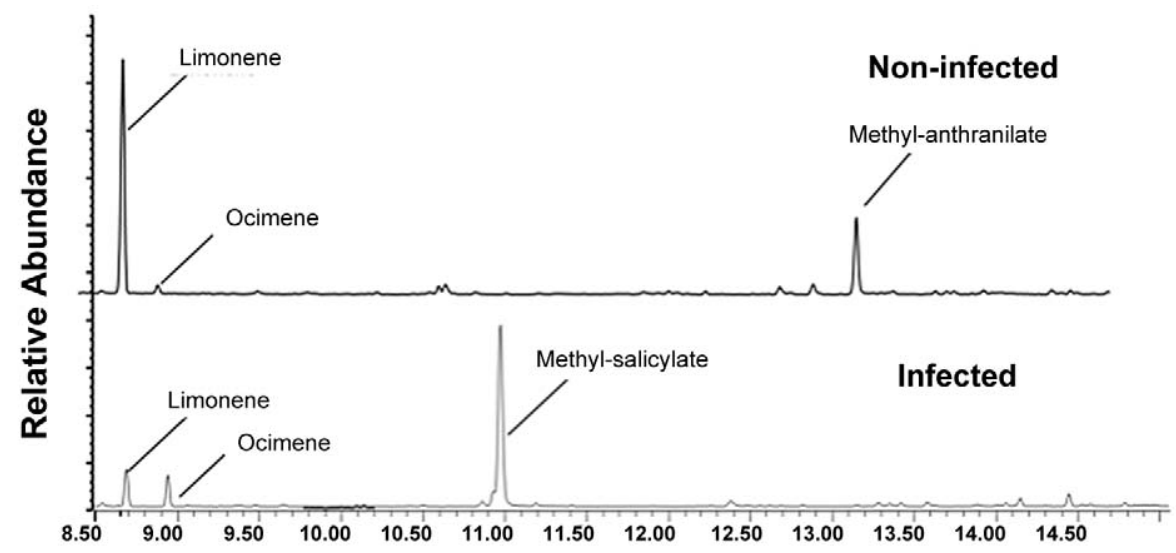

\section{Retention Time}

Figure 5. Chromatograms displaying volatile differences between Las-infected and non-infected plants. Release of methyl salicylate was significantly greater from plants infected with Las, while release of D-limonene and methyl anthranilate was significantly greater from noninfected plants.

doi:10.1371/journal.ppat.1002610.g005 
Table 4. Responses of Diaphorina citri when assayed with synthetic volatiles identified from Las-infected and non-infected citrus plants.

\begin{tabular}{|c|c|c|c|c|c|}
\hline Chemical & Dosage $(\mu \mathbf{g})$ & $\begin{array}{l}\text { Proportion of } D \text {. citri } \\
\text { responding to treatment arm }\end{array}$ & $\begin{array}{l}\text { Proportion of } D \text {. citri } \\
\text { responding to control arm }\end{array}$ & $\chi^{2}$ value & $P$ value \\
\hline \multirow[t]{6}{*}{$\dagger \beta$-ocimene (positive control) } & 0.001 & 52.22 & 47.78 & 0.18 & 0.67 \\
\hline & 0.01 & 54.46 & 45.54 & 0.8 & 0.37 \\
\hline & 0.1 & 53.19 & 46.81 & 0.38 & 0.54 \\
\hline & 1 & 60.44 & 39.56 & 3.97 & $0.05^{*}$ \\
\hline & 10 & 61.46 & 38.54 & 5.04 & $0.02 *$ \\
\hline & 100 & 62.77 & 37.23 & 6.13 & $0.01 *$ \\
\hline \multirow[t]{6}{*}{ D-limonene } & 0.001 & 56.06 & 43.94 & 0.97 & 0.32 \\
\hline & 0.01 & 60.87 & 39.13 & 2.17 & 0.14 \\
\hline & 0.1 & 54.39 & 45.61 & 0.44 & 0.51 \\
\hline & 1 & 54.65 & 45.35 & 0.74 & 0.39 \\
\hline & 10 & 60.24 & 39.76 & 3.48 & 0.06 \\
\hline & 100 & 61.54 & 38.46 & 4.85 & $0.03^{*}$ \\
\hline \multirow[t]{6}{*}{ Methyl salicylate } & 0.001 & 54 & 46 & 0.32 & 0.57 \\
\hline & 0.01 & 60.44 & 39.56 & 3.97 & $0.04 *$ \\
\hline & 0.1 & 54.76 & 45.24 & 0.38 & 0.54 \\
\hline & 1 & 45.12 & 54.88 & 0.78 & 0.38 \\
\hline & 10 & 41.03 & 58.97 & 2.51 & 0.11 \\
\hline & 100 & 39.56 & 60.44 & 3.97 & $0.04^{*}$ \\
\hline \multirow[t]{6}{*}{ Methyl anthranilate } & 0.001 & 58.06 & 41.94 & 0.81 & 0.37 \\
\hline & 0.01 & 57.14 & 42.86 & 0.71 & 0.4 \\
\hline & 0.1 & 61.76 & 38.24 & 1.88 & 0.17 \\
\hline & 1 & 57.33 & 42.67 & 1.61 & 0.2 \\
\hline & 10 & 56.1 & 43.9 & 1.22 & 0.27 \\
\hline & 100 & 52.27 & 47.73 & 0.23 & 0.63 \\
\hline
\end{tabular}

$\dagger \beta$-ocimene carried $20-25 \%$ limonene. $P$ values labeled with* are significantly different $\left(\chi^{2}\right.$ test, $\left.P<0.05\right)$. Significant $P$ values highlighted in bold indicate attraction while remaining significant $P$ values indicate repulsion.

doi:10.1371/journal.ppat.1002610.t004

to infected plants, which was likely mediated by a volatile cue (consistent with both persistent and non-persistent virus examples $[3,9]$ ), psyllids preferentially dispersed to non-infected plants after initial feeding on infected ones (consistent with non-persistent virus example [9]).

Pathogen spread may be favored in an environment with a low frequency of infected plants, when vectors prefer infected plants [80]. However, in an environment with a high frequency of infected plants, pathogen spread may be favored when vectors prefer non-infected plants [80]. More recent mathematical modeling similarly suggests that when vectors prefer to orient to infected plants, pathogen spread is rapid when the frequency of plant infection is low, but pathogen spread is slow when most plants are infected [57]. Moreover, vector preference for infected versus non-infected plants is partitioned into orientation preference and feeding preference and these two distinct suites of behavior affect pathogen spread differently, depending on whether vectors prefer infected versus non-infected plants [57]. While feeding preference for infected plants may decrease pathogen spread, orientation preference for infected plants may lead to rapid pathogen spread [57]. Acquisition of Las by D. citri can occur after 30 minutes to $24 \mathrm{hr}$ of feeding [30,33]. Therefore, initial landing by psyllids on infected plants for $24 \mathrm{hr}$ or longer is sufficient for acquisition of the pathogen. Subsequent movement of psyllids from infected to non-infected plants will result in inoculation of new plants as demonstrated by the current results. Therefore, possible manipulation of $D$. citri behavior due to Las infection of plants may increase pathogen spread in the field; however, this will likely depend on the frequency of plant infection [57]. The effect of vector preference on pathogen spread depends on several other factors, including the mode of pathogen transmission, latency period, vector movement behavior, and the combined dynamic spatial patterns of the plant, pathogen, and vector $[57,80]$.

Las-infected plants were deficient in nitrogen, phosphorus, magnesium, zinc, and iron, but were characterized by higher concentrations of potassium and boron. It is possible that infected plants are a sub-optimal host for $D$. citri because of a nutritional imbalance caused by Las infection. Phloem-feeding plant hoppers (Prokelisia dolus) disperse to higher quality Spartina plants when reared on nitrogen and phosphorus deficient plants [81]. Also, increased nitrogen content improves the performance of leaf-feeding aphids (Metopolophium dirhodum) on wheat and barley [81-83]. Physiologically, nitrogen is essential for insect growth, survival, and reproduction due to its fundamental role in protein synthesis [8488]. Phosphorus acts against viral disease by promoting plant maturity, thus restricting pathological effects of virus infection [89]. However, plant nutrient deficiencies can have a negative or positive effect on population dynamics of phloem feeding insects. For example, potassium deficiency in soybean increases fecundity and population growth of soybean aphid [90-92]. 
The nutrient analyses described in the current study only addressed the elemental composition of leaf tissues. There may be several other unidentified factors including sugars, amino acids, and proteins that could have contributed to the movement of $D$. citri from infected to non-infected plants. D. citri feed specifically within phloem cells, obtaining nutrition from free amino acids, proteins and sugars [28], which are known to affect vector growth [2,71,93-94]. Further comparisons of the elemental composition of psyllids and phloem tissues should help elucidate how host quality affects movement of $D$. citri. Las-infected leaves have been reported to accumulate up to 7.9-fold more starch than noninfected leaves, resulting in blockage of the phloem vessels [95]; however, the effect of starch accumulation on D. citri nutrition is still unknown. Starch accumulation and callose formation in rice leaves is reported to increase plant resistance to the brown plant hopper, Nilaparvata lugens, by preventing phloem ingestion [96]. In a similar experiment, plants infected with Zucchini yellow mosaic virus (ZYMV) were characterized by lower total protein and sugar content than non-infected plants [71]. However, both ZYMVinfected and non-infected plants had identical total amino acid contents and Aphis gossypii lived longer and produced more offspring on infected than on non-infected plants [71].

In summary, Las-infected plants were initially more attractive to D. citri adults than non-infected plants; however, psyllids dispersed subsequently to non-infected plants to make them their preferred location of settling rather than infected plants. Consistent with the "deceptive host phenotype" hypothesis [9], vectors were 'deceptively' attracted to the nutritionally suboptimal infected host plants during the initial settling period, which was of sufficient duration for $D$. citri to acquire the Las pathogen. Thus, the pathogen may be indirectly modifying the behavior of the vector by inducing changes in the attractiveness of the host plant through olfactory cues. This scenario suggests a mechanism for spread of the pathogen in the field because initial attraction and feeding of $D$. citri on infected host plants should facilitate acquisition of the pathogen, while subsequent movement away from potentially suboptimal infected plants should facilitate inoculation of non-infected plants. Our results indicate that MeSA may be the specific chemical cue mediating initial psyllid attraction to Las-infected plants. It is possible that changes in nutritional content of plants stimulate subsequent dispersal of psyllids from infected to uninfected plants; however, this will require further investigation.

\section{Materials and Methods}

\section{Maintenance of insect, pathogen and host plants}

Non-infected adult $D$. citri used in behavioral bioassays were obtained from a laboratory culture at the University of Florida, Citrus Research and Education Center (Lake Alfred, USA). The culture was established in 2000 from field populations in Polk Co., FL, USA $\left(28.0^{\prime} \mathrm{N}, 81.9^{\prime} \mathrm{W}\right)$ prior to the discovery of HLB in FL. The culture is maintained without exposure to insecticides on sour orange (Citrus aurantium L.) and 'Hamlin' orange [C. sinensis (L.) Osb.]. Monthly testing of randomly sampled D. citri nymphs, adults, and plants by quantitative real-time polymerase chain reaction (qPCR) assays is conducted to confirm that psyllids and plants in this culture are free of Las.

Las-infected $D$. citri were obtained from Las-infected $C$. aurantium and $C$. sinensis plants maintained in a secure quarantine facility at the University of Florida, Citrus Research and Education Center. Routine sampling indicated that about $70 \%$ of $D$. citri obtained from this colony were positive for Las when tested in qPCR assays. Both colonies were maintained at $27 \pm 1{ }^{\circ} \mathrm{C}, 63 \pm 2 \% \mathrm{RH}$, and under a L14:D10 hour photoperiod. Non-infected and Las- infected D. citri cultures were maintained in double-screened, $3.7 \times 4.6 \mathrm{~m}$ secure enclosures located in separated buildings and with minimal risk of cross contamination.

Las infection in host plants was maintained by graft-inoculation of non-infected $C$. sinensis with Las-infected key lime (Citrus aurantifolia) budwood collected from citrus groves in Immokalee, FL, USA. Grafted plants were tested for Las infection by qPCR four months after grafting. Plants that tested positive for Las were used in experiments and for maintenance of Las cultures. Cultures of Las-infected plants were maintained through graft-inoculations because of low transmission efficiency of D. citri adults [19]. Because Las is not seed transmissible [97], Las-free host plants used in experiments were cultivated from $C$. sinensis seed or obtained as potted seedlings from an HLB-free commercial nursery to minimize the risk of undetectable latent infection of Las in grafted plants. The nursery-obtained plants were confirmed negative for Las infection by qPCR. All infected plants used for experiments exhibited minor or no symptoms, ranging from 0 to 1 on a graded symptom scale of 1 to 10 . Non-infected and Lasinfected plants were maintained in separate secure enclosures with minimal risk of cross contamination as described above.

\section{Detection of Las in insect and plant samples}

Dual-labeled probes were used to detect Las in D. citri and citrus plants using an ABI 7500 system (Applied Biosystems, Foster City, CA) in a multiplex TaqMan qPCR assay described in $[19,98]$. DNA from insect and plant samples was isolated using the DNeasy blood and tissue or DNeasy plant kits (Qiagen Inc, Valencia, CA), respectively. Las-specific $16 \mathrm{~S}$ rDNA from psyllid and plant extracts was amplified using probe-primer sets targeting internal control sequences specific to D. citri [insect wingless] or plant [cytochrome oxidase] gene regions [19,98-99].

DNA amplifications were conducted in 96-well MicroAmp reaction plates (Applied Biosystems). Quantitative PCR reactions consisted of an initial denaturation step of $95^{\circ} \mathrm{C}$ for $10 \mathrm{~min}$ followed by 40 cycles of $95^{\circ} \mathrm{C}$ for $15 \mathrm{~s}$ and $60^{\circ} \mathrm{C}$ for $60 \mathrm{~s}$. Each $96-$ well plate containing $D$. citri samples included a no template control, a positive control (Las DNA in DNA extractions from $D$. citr), and a negative control (no Las DNA in DNA extractions from $D$. citr ). Likewise, plates containing plant samples included a no template control, a positive control (Las DNA in DNA extractions from plant), and a negative control (no Las DNA in DNA extractions from plant). Reactions were considered positive for either target sequence if the cycle quantification $(\mathrm{Cq})$ value, determined by the ABI 7500 Real-Time software (version 1.4, Applied Biosystems), was $\leq 32$ [19].

\section{Response of psyllids to host plant odors}

A custom designed two-port divided T-olfactometer [Analytical Research Systems (ARS), Inc. Gainesville, FL] that has been thoroughly described in [100] was used to evaluate the behavioral response of $D$. citri. Briefly, the olfactometer consisted of a $30 \mathrm{~cm}$ long glass tube with $3.5 \mathrm{~cm}$ internal diameter that is bifurcated into two equal halves with a Teflon strip forming a T-maze. Each half served as an arm of the olfactometer enabling the $D$. citri to make a choice between two potential odor fields. The olfactometer arms were connected to odor sources placed in $35 \mathrm{~cm}$ tall $\times 15 \mathrm{~cm}$ wide dome shaped guillotine volatile collection chambers (GVCG) (ARS, Gainesville, FL) through Teflon-glass tube connectors. The odor sources comprised 14-16 week old Las-infected or noninfected C. sinensis plants placed into the GVCG. Purified and humidified air was pushed through the GVCG via two pumps connected to an air delivery system (ARS, Gainesville, FL). A constant airflow of $0.1 \mathrm{~L} / \mathrm{min}$ was maintained through both arms 
of the olfactometer. The olfactometer was housed within a temperature-controlled room and positioned vertically under a fluorescent 900-lux light bulb within a fiberboard box for uniform light diffusion. This positioning took advantage of the negative geotactic and positive phototactic response of D. citri [100]. D. citri adults were released individually into the inlet adapter at the base of the olfactometer. An odor source was randomly assigned to one of the arms of the olfactometer at the beginning of each bioassay and was reversed after every 30 insects to eliminate positional bias. Initially, D. citri adults were exposed to clean air vs. clean air in the olfactometer to verify the absence of positional bias. Thereafter, the behavioral response of non-infected or Lasinfected $D$. citri was tested against non-infected versus Lasinfected plants. D. citri adults were also exposed to non-infected grafted (sham grafted) vs. non-grafted-non-infected plants to determine the effects of grafting only on $D$. citri behavior. For each treatment, $C$. sinensis plants were grafted with $C$. aurantifolia budwood four months prior to initiating behavioral experiments. A minimum of 150 male or female $D$. citri adults was examined per treatment combination (five replications of 30 D. citri). Each $D$. citri that responded to odors was individually subjected to qPGR to determine Las infection status using the procedures described above. Chi square $\left(\chi^{2}\right)$ tests were used to compare between the numbers of $D$. citri entering the treatment or control arm in the T-maze olfactometer.

\section{Host plant selection under light or dark conditions}

Light conditions. To evaluate settling preference of $D$. citri on non-infected versus Las-infected plants, two non-infected and two Las-infected plants of the similar age (14-16 week old) and vigor were placed randomly into a $0.35 \times 0.35 \times 0.6 \mathrm{~m}$ observation cage (Bioquip Products, Rancho Dominguez, USA). Thereafter, 240 D. citri adults (60 per plant) were released into the center of each cage. The cages were housed under temperature-controlled conditions of $27 \pm 1{ }^{\circ} \mathrm{C}, 63 \pm 2 \% \mathrm{RH}$, and under a L14:D10 h photoperiod. There were four cages with each cage representing a single replicate. The total number of $D$. citri settling on each Lasinfected or non-infected citrus plant was recorded three and seven days after release. Experiments were conducted separately and in an identical manner for either non-infected or Las-infected $D$. citri. Each $D$. citri adult settling on a non-infected or Las-infected citrus plant was individually tested using qPCR to confirm Las infection status following the procedures described above. Citrus plants used in experiments were examined for Las infection four months after the completion of experiments.

Dark conditions. D. citri use a combination of olfactory and visual cues to locate citrus host plants [39]. Visual cues such as light and color of leaves may impact the settling preference of $D$. citri for non-infected versus Las-infected citrus plants. Therefore, an experiment was conducted under complete darkness to eliminate the role of visual cues. The materials and procedures were otherwise identical to those described above under light conditions. D. citri adults were counted three and seven days after release using a source of red light. Preliminary testing indicated that red light did not affect psyllid behavior. Furthermore, hemipterans lack red photoreceptors [101].

Numbers of $D$. citri settling on Las-infected versus non-infected citrus plants under light and dark conditions were analyzed using a repeated-measure, mixed-model, factorial analysis of variance (ANOVA) (Proc Mixed, Version 9.1, SAS Institute, Cary, NC, USA). Las infection status of citrus plants, Las infection status of $D$. citri, and gender of D. citri were included as fixed effects. Means were compared using Tukey's Honestly Significant Difference (HSD) test.

\section{Movement of $D$. citri between Las-infected and non- infected plants}

Given that initial orientation of insect vectors to plants could be different from their final settling choices [57] and both could affect pathogen spread, we evaluated movement of $D$. citri between the Las-infected and non-infected plants. A non-infected or Lasinfected plant was inserted at random into an above described observation cage. Thereafter, $60 \mathrm{D}$. citri adults were confined on this plant using a mesh sleeve for forced settling. Once all psyllids settled on the plant, an additional, randomly selected non-infected or Las-infected plant was inserted into the cage and placed $15 \mathrm{~cm}$ away from the initial plant. Immediately thereafter, the mesh sleeve was removed from the initial plant to allow psyllid movement between the two plants. The number of $D$. citri moving from the initial plant on which they settled and onto the inserted plant was counted seven days after release. Four combinations of plant pairs were examined using either non-infected or Lasinfected D. citri for a total of eight treatments. The plant combinations tested were: 1) Las-infected settling plant with a non-infected plant introduction, 2) non-infected settling plant with a Las-infected plant introduction, 3) non-infected settling plant with a non-infected plant introduction, and 4) Las-infected settling plant with a Las-infected plant introduction. The cages were housed in a temperature-controlled room at $27 \pm 1{ }^{\circ} \mathrm{C}, 63 \pm 2 \%$ RH, and under a L14:D10 h photoperiod. Each combination was replicated four times. Non-infected $D$. citri adults found moving from infected to non-infected plants were individually analyzed for Las infection by qPCR as described above. Thereafter, the inserted plants were subsequently tested for nutritional status and possible Las infection due to movement of infected psyllids. Only female psyllids were used in these experiments, because no differences were observed in behavioral responses between the sexes in preliminary tests. A two-way ANOVA was used to analyze the number of $D$. citri adults moving between plants, with psyllid status (infected or non-infected) and plant treatment pair serving as factors. Means were subsequently separated using Tukey's HSD test. D. citri adults that did not make a choice were excluded from statistical analyses.

\section{Nutritional status of Las-infected and non-infected citrus plants}

The nutritional status of Las-infected and non-infected citrus plants was analyzed by a commercial laboratory (Waters Agricultural Lab, Inc, Georgia). Leaf samples from 16 qPCRconfirmed Las-infected or non-infected plants were washed, dried and ground to pass a $0.38-\mathrm{mm}$ sieve. An individual leaf sample comprised about three $g$ of dry leaf biomass obtained from threemonth-old leaves. Leaf phosphorus, potassium, calcium, magnesium, sulfur, manganese, iron, copper, zinc, boron, silicon, sodium, molybdenum, nitrate, aluminum, and chlorine concentrations were determined by inductively coupled plasma atomic emission spectroscopy. The nutrient data obtained from Lasinfected versus non-infected plants were analyzed using twosample t-tests.

\section{Feeding efficiency of $D$. citri on non-infected versus infected plants}

The objective of these experiments was to compare feeding efficiency of $D$. citri adults on Las-infected versus non-infected plants by quantifying their honeydew excretion. Four sets of experiments were conducted to quantify honeydew excretion of psyllids after 24, 48, 72 or $96 \mathrm{hr}$ of feeding. Each experiment was replicated five times. Citrus leaf discs obtained from Las-infected 
or non-infected plants were placed individually on $1.5 \%$ agar beds within $60 \mathrm{~mm}$ plastic disposable Petri dishes. Thereafter, ten $D$. citri adults of mixed age and sex $(\sim 1: 1)$ were released into each dish. Each Petri dish was sealed with lids lined with $60 \mathrm{~mm}$ Whatman filter paper (Whatman International Ltd, Kent, UK). Petri dishes were inverted to collect honeydew droplets onto the filter paper. Dishes were maintained at $25 \pm 1{ }^{\circ} \mathrm{C}, 50 \pm 5 \% \mathrm{RH}$, and L14:D10 h photoperiod in an incubator. Collected filter papers were subjected to a ninhydrin (Sigma-Aldrich, St Louis, MO) test to facilitate counting of honeydew droplets [102-103]. Significant differences in the number of honeydew droplets excreted on Lasinfected versus non-infected leaves were determined by a two-way ANOVA with Las infection status of leaves and D. citri exposure period as independent factors. Means were compared using Tukey's HSD tests. This technique, developed by Auclair [104], has been successfully used to quantify honeydew excretion by psyllids, whiteflies, aphids and plant hoppers [102-103,105-106].

\section{Collection of plant volatiles from Las-infected or non- infected citrus plants}

Infected or non-infected plants, as described above, were confined within a GVCG (ARS, Gainesville, FL). Charcoalpurified and humidified air was drawn over plants and pulled out at a rate of $300 \mathrm{~mL}$ min-1 through a trap containing $50 \mathrm{mg}$ of Super-Q adsorbent, 800-1000 mesh (Alltech Assoc., Deerfield, Illinois, USA) for $24 \mathrm{hrs}$. Thereafter, Super-Q traps were rinsed with $150 \mu \mathrm{l}$ of dichloromethane into individual $2.0 \mathrm{ml}$ clear glass vials (Varian, Palo Alto, CA, USA, part number: 392611549 equipped with $500 \mu \mathrm{l}$ glass inserts). Volatiles were sampled from two plants simultaneously (one Las-infected and the second noninfected). A total of five plants that were previously identified as infected and five similar plants identified as non-infected were sampled.

\section{Analysis of volatiles by GC-MS}

An internal standard of n-octane (300 ng) was added to each sample prior to GC-MS analysis. A one $\mu$ l aliquot of each extract was injected onto a gas chromatograph (HP 6890) equipped with $30 \mathrm{~m} \times 0.25-\mathrm{mm}-\mathrm{ID}, \quad 0.25 \mu \mathrm{m}$ film thickness DB-5 capillary column (Quadrex, New Haven, GT, USA), interfaced to a 5973 Mass Selective Detector (Agilent, Palo Alto, CA, USA), in both electron impact (EI) and chemical ionization (CI) modes. Helium was used as the carrier gas in the constant flow mode of $30 \mathrm{~cm} /$ sec. The injector was maintained at $260^{\circ} \mathrm{C}$. The oven was programmed from 40 to $260^{\circ} \mathrm{C}$ at $7^{\circ} \mathrm{C} / \mathrm{min}$. Isobutane was used as the reagent gas for $\mathrm{CI}$, and the ion source temperature was set at $250^{\circ} \mathrm{C}$ in $\mathrm{CI}$ and $220^{\circ} \mathrm{C}$ in EI. The mass spectra were matched with NIST 2005 version 2.0 standard spectra (NIST, Gaithersburg, MD). The compounds with spectral fit values equal to or greater than 90 and appropriate LRI values were considered positive identifications. When available, mass spectra and retention times were compared to those of authentic standards. Compounds were quantified as equivalents of the total amount of $\mathrm{n}$-octane within each analyzed volatile collection sample. A more accurate quantification of MeSA was made by comparing the total ion chromatograph (TIC) EI response for standard solutions with known quantities of n-octane and MeSA. A response factor of 1.2 was then established for MeSA relative to the n-octane based values.

The resulting volatile profiles were standardized as equivalents of n-octane within each sample analyzed. The characteristic set of variables that defined a particular group (e.g. non-infected versus infected plant) was found using the 'varSelRFBoot' function of the package 'varSelRF' for the 'randomForest' analysis ( $\mathrm{R}$ software version 2.9.0, R Development Core Team 2009). We used the varSelRF algorithm with Random Forests to select the minimum set of VOCs that were characteristic of differences between infected and non-infected plants. The tree-based Random Forests algorithm performs hierarchical clustering via multi-scale and combinatorial bootstrap resampling and is most appropriate for data where the variables (VOCs in this case) outnumber the samples, and where the variables are auto correlated, which is a typical problem of conventional multivariate analysis of such data. Consequently, this type of analysis is common in bioinformatics, chemoinformatics and similar data-rich fields. We employed 200 bootstrapping iterations of the Random Forests algorithm to arrive at a minimal set of VOCs that could differentiate between infected and non-infected plants. We also calculated the mean decrease in accuracy (MDA) when individual VOCs are removed from the analysis. MDA values indicate the importance value of particular VOCs for the discrimination between treatments.

\section{Collection of volatiles from citrus plants before and during psyllid feeding}

Volatiles were collected to determine whether release of MeSA was induced by psyllid feeding. Plants were placed within a GVCC with identical flow rates and collection procedures as described above. Volatiles were collected simultaneously from three undamaged plants (no psyllid feeding) for $24 \mathrm{hrs,} \mathrm{after} \mathrm{which} \mathrm{the}$ adsorbent traps were rinsed into vials for gas chromatographymass spectrometry (GC-MS) analysis as described above for the collection of volatiles from infected and uninfected plants. Psyllids were divided by sex and randomly introduced into two of the three plant chambers. Each infested plant received 300 psyllids (one plant receiving only males and another plant receiving only females). The third plant was left uninfested as a control. Volatiles were collected from plants for $24 \mathrm{hr}$, after which traps were rinsed into vials for GC-MS analysis. Volatiles were collected in this manner on three separate dates with six plants evaluated before and after D. citri introduction and three plants serving as simultaneous undamaged controls. VOCs that were characteristic of differences between plants before and after psyllid feeding were determined as described above. Treatment differences between individual volatiles collected from headspace of infected and noninfected plants were compared using two-sample t-tests.

\section{Behavioral response of $D$. citri to synthetic chemicals}

MeSA was released in greater quantities from Las-infected plants than non-infected plants, while MeAN and D-limonene were released in greater quantities by non-infected than infected plants (See results). Therefore, the behavioral response of $D$. citri to these synthetic chemicals was tested. A known $D$. citri attractant, $\beta$ ocimene [40], was used as a positive control. All chemicals were obtained from Sigma Aldrich (St Louis, MO) with purities ranging between 97 and $99 \%$. Purity of $\beta$-ocimene was $\geq 90 \%$ and contained a mixture of isomers comprising 20-25\% limonene. Each treatment was dissolved in $100 \mu \mathrm{l}$ of dichloromethane and pipetted onto a $2 \mathrm{~cm}$ Richmond cotton wick (Petty John Packaging, Inc. Concord, NG) at 0.001, 0.01, 0.1, 1.0, 10.0 and $100.0 \mu \mathrm{g}$ dosages. The control treatment consisted of a cotton wick impregnated with solvent only. The solvent from both treatments was allowed to evaporate within a fume hood for $30 \mathrm{~min}$ prior to assays. The bioassay procedures with synthetic chemicals were identical to those described earlier for plant samples. However, in this case, treatments (odor sources) were placed into solid phase micro extraction chambers (SPMEG) (ARS, Gainesville, FL) instead of the GVCG described above. The SPMEC consists of a straight glass tube $(17.5 \mathrm{~cm}$ long $\times 2.5 \mathrm{~cm}$ internal diameter $)$ 
supported with an inlet and outlet valve for incoming and outgoing air streams, respectively [102]. The treated and control cotton wicks were wrapped in laboratory tissue (Kim wipes, KimberlyClark, Roswell, GA) to minimize contamination and placed randomly into one of the two SPMEC enclosures that were connected to the olfactometer and the air delivery system through Teflon-glass tube connectors. Only non-infected female psyllids were assayed in these experiments, because no differences in behavioral responses were observed between the sexes or between infected and non-infected psyllids in preliminary tests. At least 120 non-infected female adults were examined per treatment combination. The treatment combinations evaluated in this set of experiment were 1) MeAN vs. clean air, 2) MeSA vs. clean air, 3) D-limonene vs. clean air, and 4) $\beta$-ocimene vs. clean air. Chi square $\left(\chi^{2}\right)$ tests were used to compare between the numbers of $D$.

\section{References}

1. Purcell A (1982) Insect vector relationships with procaryotic plant-pathogens. Ann Rev of Phytopathol 20: 397-417.

2. Purcell AH (1985) The ecology of bacterial and mycoplasma plant diseases spread by leafhoppers and planthoppers. In: Nault LR, Rodriguez JG, eds. The leafhoppers and planthoppers. New York: J Wiley \& Sons. pp 351-380.

3. Eigenbrode S, Ding H, Shiel P, Berger P (2002) Volatiles from potato plants infected with potato leafroll virus attract and arrest the virus vector, Myzus persicae (Homoptera: Aphididae). Proc R Soc Lond B Biol Sci 269: 455-460.

4. Jimenez-Martinez E, Bosque-Perez N, Berger P, Zemetra R, Ding H, et al. (2004) Volatile cues influence the response of Rhopalosiphum padi (Homoptera: Aphididae) to barley yellow dwarf virus-infected transgenic and untransformed wheat. Environ Entomol 33: 1207-1216.

5. Belliure B, Janssen A, Maris P, Peters D, Sabelis M (2005) Herbivore arthropods benefit from vectoring plant viruses. Ecol Lett 8: 70-79.

6. Fereres A, Moreno A (2009) Behavioural aspects influencing plant virus transmission by homopteran insects. Virus Res 141: 158-168.

7. Mann R, Sidhu J, Butter N, Sohi A, Sekhon P (2008) Performance of Bemisia tabaci (Hemiptera : Aleyrodidae) on healthy and cotton leaf curl virus infected cotton. Fla Entomol 91: 249-255.

8. Mann RS, Sidhu JS, Butter NS (2009) Settling preference of the whitefly Bemisia tabaci (Hemiptera: Aleyrodidae) on healthy versus cotton leaf curl virusinfected cotton plants. Int J Trop Insect Sci 29: 57-61

9. Mauck K, De Moraes C, Mescher M (2010) Deceptive chemical signals induced by a plant virus attracts insect vectors to inferior hosts. Proc Natl Acad Sci U S A 107: 3600-3605.

10. Daugherty M, Lopes J, Almeida R (2010) Vector within-host feeding preference mediates transmission of a heterogeneously distributed pathogen. Ecol Entomol 35: 360-366.

11. Schoonhoven L (2005) Insect-plant relationships: the whole is more than the sum of its parts. Entomol Exp Appl 115: 5-6.

12. Jiménez-Martínez ES, Bosque-Pérez NA, Berger PA, Zemetra RS (2004) Life history of the bird cherryoat aphid, Rhopalosiphum padi (Homoptera: Aphididae), on transgenic and untransformed wheat challenged with Barley yellow dwarf virus. J Econ Entomol 97: 203-212.

13. Castle SJ, Mowry TM, Berger PH (1998) Differential settling by Myzus persicae (Homoptera: Aphididae) on various viruses infected host plants. Ann Entomol Soc Am 91: 661-667.

14. De Boer J, Posthumus M, Dicke M (2004) Identification of volatiles that are used in discrimination between plants infested with prey or nonprey herbivores by a predatory mite. J Chem Ecol 34: 1045-1049.

15. Mayer CJ, Vilcinskas A, Gross J (2008a) Phytopathogen lures its insect vector by altering host plant odor. J Chem Ecol 34: 1518-1522.

16. Mayer CJ, Vilcinskas A, Gross J (2008b) Pathogen-induced release of plant allomone manipulates vector insect behavior. J Chem Ecol 34: 1518-1522.

17. Koella JC, Srensen FL, Anderson RA (1998) The malaria parasite, Plasmodium falciparum, increases the frequency of multiple feeding of its mosquito vector, Anopheles gambiae. Proc R Soc Lond B Biol Sci 265: 763-768.

18. Jiu M, Zhou XP, Liu SS (2006) Acquisition and transmission of two begomoviruses by the B and a non-B biotype of Bemisia tabaci from Zhejiang, China. J Phytopathol 154: 587-591.

19. Pelz-Stelinski KS, Brlansky RH, Ebert TA, Rogers ME (2010) Transmission parameters for Candidatus Liberibacter asiaticus by Asian citrus psyllid (Hemiptera: Psyllidae). J Econ Entomol 103: 1531-1541.

20. Roossinck MJ (2011) The good viruses: viral mutualistic symbioses. Nat Rev Microbiol 9: 99-108.

21. Huang J, Cardoza YJ, Schmelz EA, Raina R, Engelberth J (2003) Differential volatile emissions and salicylic acid levels from tobacco plants in response to different strains of Pseudomonas syringae. Planta 217: 767-775.

22. Bove JM (2006) Huanglongbing: A destructive, newly-emerging, century-old disease of citrus. J Plant Pathol 88: 7-37. citri entering the treatment or control arm in the T-maze olfactometer.

\section{Acknowledgments}

We thank Michael Flores, Angel Hoyte, and Ruben Blanco for help with bioassays and for assistance in performing qPCR. We are grateful to Erik Wenninger and Jürgen Gross for providing constructive criticism on a previous version of the manuscript. Previous versions of the manuscript were also significantly improved by three anonymous reviewers.

\section{Author Contributions}

Conceived and designed the experiments: LLS RSM JGA. Performed the experiments: RSM JGA SLH. Analyzed the data: RSM JGA KSPS LLS. Contributed reagents/materials/analysis tools: RSM KSPS ST HTA LLS. Wrote the paper: RSM LLS KSPS JGA.

23. Garnier M, Danel N, Bove JM (1984) Etiology of citrus greening disease. Ann Inst Pasteur Mic A135: 169-179.

24. Jagoueix S, Bove JM, Garnier M (1997) Comparison of the 16S/23S ribosomal intergenic regions of "Candidatus Liberobacter asiaticum" and "Candidatus Liberobacter africanum," the two species associated with citrus huanglongbing (greening) disease. Int J Syst Bacteriol 47: 224-227.

25. Hocquellet A, Toorawa P, Bove JM, Garnier M (1999) Detection and identification of the two Candidatus Liberobacter species associated with citrus huanglongbing by PCR amplification of ribosomal protein genes of the beta operon. Mol Cell Probe 13: 373-379.

26. Sagaram US, DeAngelis KM, Trivedi P, Andersen GL, Lu S-E, et al. (2009) Bacterial diversity analysis of huanglongbing pathogen-infected citrus, using phylochip arrays and 16S rRNA gene clone library sequencing. Appl Environ Microbiol 75: 1566-1574.

27. Christensen NM, Nicolaisen M, Hansen M, Schulz A (2004) Distribution of phytoplasmas in infected plants as revealed by real-time PCR and bioimaging. Mol Plant Microbe Int 17: 1175-1184

28. Halbert SE, Manjunath KL (2004) Asian citrus psyllids (Sternorrhyncha: Psyllidae) and greening disease of citrus: A literature review and assessment of risk in Florida. Fla Entomol 87: 330-353.

29. Lopes SA, Bertolini E, Frare GF, Martins EC, Wulff NA, et al. (2009) Graft transmission efficiencies and multiplication of 'Candidatus Liberibacter americanus' and ' $\mathrm{Ca}$. Liberibacter asiaticus' in citrus Plants. Phytopathology 99: 301-306.

30. Capoor SP, Rao DG, Viswanath SM (1974) Greening disease of citrus in the Deccan Trap Country and its relationship with the vector, Diaphorina citri Kuwayama. Proc Sixth Conf IOCV. pp 43-49.

31. Roistacher CN (1991) Greening. In: CN. Roistacher, ed. Techniques for biological detection of specific citrus graft transmissible diseases. Rome: Food and Agricultural Organization of the United Nations. pp 35-45.

32. Hung TH, Hung SC, Chen CN, Hsu MH, Su HJ (2004) Detection by PCR of Candidatus Liberibacter asiaticus, the bacterium causing citrus huanglongbing in vector psyllids: application to the study of vector-pathogen relationships. Plant Pathol 53: 96-102.

33. Inoue H, Ohnishi J, Ito T, Tomimura K, Miyata S, et al. (2009) Enhanced proliferation and efficient transmission of Candidatus Liberibacter asiaticus by adult Diaphorina citri after acquisition feeding in the nymphal stage. Ann Appl Biol 155: 29-36.

34. Moll JN, Martin MM (1973) Electron microscope evidence that citrus psylla Trioza-erytreae is a vector of greening disease in South Africa. Phytophylactica 5: $41-44$.

35. McGlean APD, Schwarz RE (1970) Greening or blotchy-mottle disease of citrus. Phytophylactica 2: 177-193.

36. Tiwari S, Lewis-Rosenblum H, Pelz-Stelinski K, Stelinski LL (2010) Incidence of Candidatus Liberibacter asiaticus infection in abandoned citrus occurring in proximity to commercially managed groves. J Econ Entomol 103: 1972-1978.

37. Wenninger EJ, Hall DG (2007) Daily timing of mating and age at reproductive maturity in Diaphorina citri (Hemiptera: Psyllidae). Fla Entomol 90: 715-722.

38. Wenninger EJ, Hall DG (2008) Importance of multiple mating to female reproductive output in Diaphorina citri. Physiol Entomol 33: 316-321.

39. Wenninger EJ, Stelinski LL, Hall DG (2009) Roles of olfactory cues, visual cues, and mating status in orientation of Diaphorina citri Kuwayama (Hemiptera: Psyllidae) to four different host plants. Environ Entomol 38: 225-234.

40. Patt JM, Setamou M (2010) Responses of the Asian citrus psyllid to volatiles emitted by the flushing shoots of its rutaceous host plants. Environ Entomol 39: 618-624.

41. Pare PW, Tumlinson JH (1999) Plant volatiles as a defense against insect herbivores. Plant Physiol 121: 325-331.

42. Holopainen JK (2004) Multiple functions of inducible plant volatiles. Trends Plant Sci 9: 529-533. 
43. Mumm R, Posthumus MA, Dicke M (2008) Significance of terpenoids in induced indirect plant defence against herbivorous arthropods. Plant Cell Environ 31: 575-585.

44. Walling LL (2000) The myriad plant responses to herbivores. J Plant Growth Regul 19: 195-216.

45. Kessler A, Baldwin IT (2001) Defensive function of herbivore-induced plant volatile emissions in nature. Science 291: 2141-2144.

46. Kost C, Heil M (2006) Herbivore-induced plant volatiles induce an indirect defence in neighbouring plants. J Ecol 94: 619-628.

47. Stout MJ, Thaler JS, Thomma B (2006) Plant-mediated interactions between pathogenic microorganisms and herbivorous arthropods. Ann Rev Entomol 51: 663-689.

48. Wei J, Wang L, Zhu J, Zhang S, Nandi OI, et al. (2007) Plants attract parasitic wasps to defend themselves against insect pests by releasing hexenol. Plos One 2: e852.

49. Liu G, Ji Y, Bhuiyan NH, Pilot G, Selvaraj G, et al. (2010) Amino acid homeostasis modulates salicylic acid-associated redox status and defense responses in Arabidopsis. Plant Cell 22: 3845-3863.

50. Griebel T, Zeier J (2010) A role for beta-sitosterol to stigmasterol conversion in plant-pathogen interactions. Plant J 63: 254-268.

51. Mishina TE, Zeier J (2007) Bacterial non-host resistance: interactions of Arabidopsis with non-adapted Pseudomonas syringae strains. Physiola Plantarum 131: 448-461.

52. Mishina TE, Zeier J (2007) Pathogen-associated molecular pattern recognition rather than development of tissue necrosis contributes to bacterial induction of systemic acquired resistance in Arabidopsis. Plant J 50: 500-513.

53. Mishina TE, Griebel T, Geuecke M, Attaran E, Zeier J (2008) New insights into the molecular events underlying systemic acquired resistance. In: Volume 6 Proceedings of the 13th International Congress on Molecular Plant-Microbe Interactions, Biology of plant-microbe interactions; 21-27 July 2007; Sorrento, Italy. $81 \mathrm{p}$

54. Dean JV, Delaney SP (2008) Metabolism of salicylic acid in wild-type, ugt74f1 and ugt74f2 glucosyltransferase mutants of Arabidopsis thaliana. Physiol Plantarum 132: 417-425.

55. Attaran E, Zeier TE, Griebel T, Zeier J (2009) Methyl salicylate production and jasmonate signaling are not essential for systemic acquired resistance in Arabidopsis. Plant Cell 21: 954-971.

56. Thaler JS, Agrawal AA, Halitschke R (2010) Salicylate-mediated interactions between pathogens and herbivores. Ecology 91: 1075-1082.

57. Sisterson MS (2008) Effects of insect-vector preference for healthy or infected plants on pathogen spread: Insights from a model. J Econ Entomol 101: 1-8.

58. Srininvasan R, Alvarez JM, Eigenbrode SD, Bosque-Perez NA (2006) Influence of hairy nightshade Solanum sarrachoides (Sendtner) and Potato leafroll virus (Luteoviridae : Polerovirus) on the host preference of Myzus persicae (Sulzer) (Homoptera : Aphididae). Environ Entomol 35: 546-553.

59. Ngumbi E, Eigenbrode SD, Bosque-Perez NA, Ding H, Rodriguez A (2007) Myzus persicae is arrested more by blends than by individual compounds elevated in headspace of PLRV-Infected potato. J Chem Ecol 33: 1733-1747.

60. Roder G, Rahier M, Naisbit RE (2011) Do induced responses mediate the ecological interactions between the specialist herbivores and phytopathogens of an alpine plant? Plos One 6: e19571.

61. Ajayi O, Dewar AM (1983) The effects of barley yellow dwarf virus, aphids and honeydew on cladosporium infection of winter-wheat and barley. Ann Appl Biol 102: 57-65.

62. Fereres A, Kampmeier GE, Irwin ME (1999) Aphid attraction and preference for soybean and pepper plants infected with potyviridae. Ann Entomol Soc Am 92: 542-548

63. Marucci RC, Lopes JRS, Vendramim JD, Corrente JE (2005) Influence of Xylella fastidiosa infection of citrus on host selection by leafhopper vectors. Entomol Exp Appl 117: 95-103.

64. Strauss E (2009) Phytoplasma research begins to bloom. Science 325: 388-390.

65. Dugo G, Di Giacomo A (2002) Citrus: The genus citrus. medicinal and aromatic plants-industrial profiles series. New York: Taylor \& Francis Group, CRG Press. 504 p.

66. Jabalpurwala FA, Smoot JM, Rouseff RL (2009) A comparison of citrus blossom volatiles. Phytochem 70: 1428-1434.

67. Lin SY, Roan SF, Lee CL, Chen IZ (2010) Volatile organic components of fresh leaves as indicators of indigenous and cultivated citrus species in Taiwan. Biosci, Biotechnol, Biochem 74: 806-811.

68. Webster B, Bruce TJA, Pickett JA, Hardie J (2008) Olfactory recognition of host plants in the absence of host-specific volatile compounds. Commun Integr Biol 1: 167-169.

69. Webster B, Bruce TJA, Pickett JA, Hardie J (2010) Volatiles functioning as host cues in a blend become nonhost cues when presented alone to the black bean aphid. Anim Behav 79: 451-457.

70. Macias W, Mink GI (1969) Preference of green peach aphids for virus-infected sugarbeet leaves. J Econ Entomol 62: 28-99.

71. Blua MJ, Perring TM (1992) Effects of zucchini yellow mosaic-virus on colonization and feeding-behavior of Aphis-gossypii (Homoptera, Aphididae) alatae. Environ Entomol 21: 578-585.

72. Kaloshian I, Walling LL (2005) Hemipterans as plant pathogens. Ann Rev Phytopathol 43: 491-521

73. Musser RO, Cipollini DF, Hum-Musser SM, Williams SA, Brown JK, et al. (2005) Evidence that the caterpillar salivary enzyme glucose oxidase provides herbivore offense in Solanaceous plants. Arch Insect Biochem Physiol 58: 128-137.

74. Ryals JA, Neuenschwander UH, Willits MG, Molina A, Steiner HY, et al. (1996) Systemic Acquired Resistance. Plant Cell 8: 1809-1819.

75. Durrant WE, Dong X (2004) Systemic acquired resistance. Ann Rev Phytopathol 42: 185-209.

76. Zarate SI, Kempema LA, Walling LL (2007) Silverleaf whitefly induces salicylic acid defenses and suppresses effectual jasmonic acid defenses. Plant Physiol 143: 866-875.

77. Walling LL (2008) Avoiding effective defenses: strategies employed by phloemfeeding insects. Plant Physiol 146: 859-866.

78. Montllor CB, Gildow FE (1986) Feeding responses of two grain aphids to barley yellow dwarf virus-infected oats. Entomol Exp Appl 42: 63-69.

79. Castle SJ, Berger PH (1993) Rates of growth and increase of Myzus persicae om virus-infected potatoes according to type of virus-vector relationship. Entomol Exp Appl 69: 51-60.

80. McElhany P, Real LA, Power AG (1995) Vector preference and disease dynamics: a study of barley yellow dwarf virus. Ecology 76: 444-457.

81. Huberty AF, Denno RF (2006) Consequences of nitrogen and phosphorus limitation for the performance of two planthoppers with divergent life-history strategies. Oecologia 149: 444-455.

82. Honek A (1991) Environment stress, plant-quality and abundance of cereal aphids (hom, aphididae) on winter-wheat. J Appl Entomol 112: 65-70.

83. Honek A (1991) Nitrogen-fertilization and abundance of the cereal aphids Metopolophium dirhodum and Sitobion avenae (Homoptera, Aphididae). Z Pflanzenk Pflanzen 98: 655-660.

84. Vanemden HF (1966) Studies on relations of insect and host plant .3. a comparison of reproduction of Brevicoryne brassicae and Myzus persicae (hemiptera - aphididae) on brussels sprout plants supplied with different rates of nitrogen and potassium. Entomol Exp Appl 9: $444-460$.

85. Kerslake JE, Woodin SJ, Hartley SE (1998) Effects of carbon dioxide and nitrogen enrichment on a plant-insect interaction: the quality of Calluna vulgaris as a host for Operophtera brumata. New Phytol 140: 43-53.

86. Ayres MP, Wilkens RT, Ruel JJ, Lombardero MJ, Vallery E (2000) Nitrogen budgets of phloem-feeding bark beetles with and without symbiotic fungi. Ecology 81: 2198-2210.

87. Bentz JA, Townsend AM (2001) Leaf element content and utilization of maple and elm as hosts by the potato leafhopper (Homoptera: Cicadellidae). Environ Entomol 30: 533-539.

88. Sterner R, Elser J (2002) Ecological stoichiometry: The biology of elements from molecules to the biosphere. New Jersey: Princeton University Press. 584 p.

89. Chaboussou F (2004) Healthy crops: A new agricultural revolution. Charlbury, UK: Jon Carpenter Publishing. 244 p.

90. Myers SW, Gratton C, Wolkowski RP, Hogg DB, Wedberg JL (2005) Effect of soil potassium availability on soybean aphid (Hemiptera: Aphididae) population dynamics and soybean yield. J Econ Entomol 98: 113-120.

91. Walter AJ, DiFonzo CD (2007) Soil potassium deficiency affects soybean phloem nitrogen and soybean aphid populations. Environ Entomol 36: 26-33.

92. Noma T, Gratton C, Colunca-Garcia M, Brewer MJ, Mueller EE, et al. (2010) Relationship of soybean aphid (Hemiptera: Aphididae) to soybean plant nutrients, landscape structure, and natural enemies. Environ Entomol 39: $31-41$

93. Weibull J, Melin G (1990) Free amino acid content of phloem sap from Brassica plants in relation to performance of Lipaphis erysimi (Hemiptera: Aphididae). Ann Appl Biol 116: 417-423.

94. Blua MJ, Perring TM, Madore MA (1994) Plant virus-induced changes in aphid population development and temporal fluctuations in plant nutrients. J Chem Ecol 20: 691-707.

95. Fan J, Chen C, Brlansky RH, Gmitter FG, Jr., Li ZG (2010) Changes in carbohydrate metabolism in Citrus sinensis infected with 'Candidatus Liberibacter asiaticus'. Plant Pathol 59: 1037-1043.

96. Hao P, Liu C, Wang Y, Chen R, Tang M, et al. (2008) Herbivore-induced callose deposition on the sieve plates of rice: An important mechanism for host resistance. Plant Physiol 146: 1810-1820.

97. Hartung JS, Halbert SE, Pelz-Stelinski KS, Brlansky RH, Chen C, et al. (2010) Lack of evidence for transmission of 'Candidatus liberibacter asiaticus' through citrus seed taken from affected fruit. Plant Dis 94: 1200-1205.

98. Li WB, Hartung JS, Levy L (2006) Quantitative real-time PCR for detection and identification of Candidatus Liberibacter species associated with citrus huanglongbing. J Microbiol Meth 66: 104-115.

99. Thao ML, Baumann P (2000) Evolutionary relationships of psyllid endosymbionts based on 16S rDNA, 23S rDNA and atpAGD analyses. Abstracts of the General Meeting of the American Society for Microbiology 100: 632.

100. Mann RS, Rouseff RL, Smoot JM, Castle WS, Stelinski LL (2011) Sulfur volatiles from Allium spp. affect Asian citrus psyllid, Diaphorina citri Kuwayama (Hemiptera: Psyllidae), response to citrus volatiles. Bull Entomol Res 101: $89-97$.

101. Briscoe AD, Chittka L (2001) The evolution of color vision in insects. Ann Rev Entomol 46: 471-510.

102. Nauen R, Elbert A (1997) Apparent tolerance of a field-collected strain of Myzus nicotianae to imidacloprid due to strong antifeeding responses. Pestic Sci 49: 252-258. 
103. Boina DR, Onagbola EO, Salyani M, Stelinski LL (2009) Antifeedant and sublethal effects of imidacloprid on Asian citrus psyllid, Diaphorina citri. Pest Manag Sci 65: 870-877.

104. Auclair JL (1959) The influence of dietary amino acids on the blood amino acids of the German cockroach, Blattella germanica (L.). J Insect Physiol 3: $127-31$
105. Paguia P, Pathak MD, Heinrichs EA (1980) Honeydew excretion measurement techniques for determining differential feeding activity of biotypes of Nilaparvata lugens on rice varieties. J Econ Entomol 73: 35-40.

106. Nisbet AJ, Woodford JAT, Strang RHC (1994) Quantifying aphid feeding on non-radioactive food sources. Entomol Exp Appl 72: 85-89. 